\title{
5.5
}

\section{In terms of Brexit}

Many political and constitutional steps are needed in order for the UK to leave the European Union, after 45 years as a full member. Cumulatively they form one of the biggest constitutional changes in British history, and one dogged by intense controversy and disputes. Joelle Grogan examines how far the Brexit process can meet democratic criteria for such a momentous transition, or may fall short of these standards.

\section{What does democracy require for the way in which the British withdrawal from the EU is decided, implemented and achieved?}

Only Parliament can finally decide the terms on which Brexit is achieved. The 2016 referendum provided a significant statement of popular support to leave the EU. But giving effect to this decision is a highly technical process that only Parliament can navigate successfully - because there cannot be a plebiscite on each sub-issue. Parliament is accountable only to the electorate. The composition of voters can change at the next election, and previous voters can also change their minds.

$\checkmark$ Cross-party co-operation and engagement are needed, especially in a hung parliament, as now. The full Brexit process will not be resolved by March 2019, but will take several more years, perhaps even multiple parliamentary terms. So it necessitates careful deliberation from all MPs and parties in Parliament. Parliamentary democracy ought to epitomise informed debate by elected representatives and the capacity to compromise on the best course of action.

$\downarrow$ Government must openly communicate with the public about the achievable outcomes and feasible timelines for Brexit. Acknowledging the complexity of the task can (re)build trust with negotiating partners, and build public recognition of the need for an extension to the time to negotiate a withdrawal agreement or a transition period.

A progressive, sectoral and methodical plan of law reform is needed, prioritising the rule of law. Separating the UK from the EU is a highly technical and challenging process of law reform. There is now no pre-EU/European Community law for the UK to rely upon, and people have built their lives and businesses on the certainty of 
the law of the last 40 years. Sensibly reforming the law to reflect the UK in a postBrexit era entails committing to prioritise legal certainty and accountability above expediency and ease of policy implementation. It will also require a well-resourced and enlarged civil service, with open and transparent consultation processes.

* Robust accountability mechanisms are needed to scrutinise government decisions taken under the Brexit process. The 2016 referendum gave a mandate to withdraw as a member of the European Union, but not to radically change the foundations of the British legal system. Such delegated powers as are necessary to quickly address deficiencies in the law arising from Brexit must be balanced by effective and robust oversight mechanisms. This includes acknowledging the central duty of the judiciary to review these decisions so as to uphold parliamentary sovereignty and the rule of law.

The process must fully involve the devolved legislatures. Scotland and Northern Ireland voted in the majority to remain, and the land border with the Republic of Ireland makes Brexit's implementation of critical importance to Northern Ireland. For both Scotland and Wales, the previous devolution legislation assigned all powers to the devolved Parliament or Assembly that were not reserved to the UK. Yet the May government's Brexit process seems to involve two stages, in which all powers shift back to Westminster, and only then are devolved down - potentially breaching the previous constitutional understanding (see Chapter 5.6). Navigating this cannot be done by Westminster imposing a solution.

Brexit is in the eye of the beholder. The 2016 referendum result is seen by many Leavers as the ultimate expression of the popular will of the British people. But Remainers often picture it instead as the upshot of a poorly framed question put to an ill-informed, and underrepresentative segment of the population - even the product of a 'gerrymander'. In the context of such all or nothing Brexit paradigms, auditing the democratic legitimacy of Brexit is challenging. However, there are clear and manifest issues with regards to the process by which Brexit is accomplished, rather than the outcome and the decision itself.

\section{Recent developments}

Since the 2016 referendum, subsequent change of Prime Minister, and advent of a hung parliament in mid-2017 much has happened. There was hard-fought litigation on parliamentary sovereignty to trigger Article 50, and the government decision to go ahead began a two-year countdown. The European Union (Withdrawal) Act aims to solve the issues of the separation of the UK from the EU within two years of exit day (at the end of March 2019). Very little of any of these changes has directly addressed the issues immediately pertinent to the Brexit process.

The 2017 general election was called to 'strengthen the mandate' of the Conservatives in the EU negotiations and to provide certainty in the leadership for the Brexit process, and 'stability' in government. In fact it resulted in a loss of both. While Brexit was a key election issue, neither of the top two parties engaged with each other on the detailed strategies to be pursued following the election. Both remained deeply divided on them throughout 2018 
(see Chapter 3.1). Since the election, then, the only certainty has been uncertainty, with viable Brexit options evolving in ways that have made analysis of them one day obsolete the next.

By March 2018, one year after the triggering of Article 50's two-year timeline, there was a draft agreement with the EU, though with considerable differences remaining over key issues such as the Northern Ireland border, the process of dispute resolution, and at that stage little progress on a future UK-EU relationship (post transition). By early autumn 2018 the Prime Minister had dragooned her Cabinet (after two key resignations) into accepting the 'Chequers agreement' plan for the UK to retain free trade in goods with the EU countries, but not in services - denounced by critics as a fudge. Whether this compromise would succeed against Tory backbench rebels or be accepted by the EU negotiators remained unclear at the time of writing, with the UK government also publishing papers outlining 'a calamity' if the UK should instead leave on a 'no deal' basis.

\section{Strengths, Weaknesses, Opportunities, Threats (SWOT) analysis}

\section{Current strengths}

The electorate's 2016 rejection of membership of the European Union is an assertion of the importance of national sovereignty, and the desire for national control over laws, especially the key issue of migration.

In promptly following up the Brexit vote, the government shows democratic respect for the (narrow) majority result of the EU referendum.

\section{Current weaknesses}

By respecting a slim majority vote in an advisory referendum, where the campaign itself was subject to criticism for the lack of informed debate and uncertain positions, the government is pursuing a mandate which is unclear in its terms, meaning or consequences. What national sovereignty concepts can mean in the contemporary world remains unclear.

One consequence of according so much weight to an unclear mandate is to weaken the power of Parliament. Open debate about the consequences of Brexit has been curtailed as MPs face a backlash by pro-Brexit media and politicians, whereby expressing any doubts about the consequences of Brexit is seen as an attempt to undermine the people's verdict.

The rights of millions of EU and UK citizens are being devalued to 'bargaining chips' in negotiations between the EU and the UK. Such a debasement of the meaning of citizenship and individual rights is a violation of basic tenants of a democracy. 


\section{Current strengths}

\section{Current weaknesses}

The long delays in developing any clear UK negotiating position, and its late arrival in summer 2018, mean that negotiations with the EU may come to an end without a deal having been achieved. Embracing the possibility of a 'no deal Brexit' is a failing in the withdrawal negotiation process, because the public cannot easily estimate what may follow the March 2019 deadline on this pathway.

Rare and unjustified public attacks on the judiciary by leading politicians and powerful media following the Miller decision are a concerning trend, one eroding the separation of powers and respect for the institutions of democracy.

\section{Future opportunities}

The Brexit process presents an unprecedented opportunity for large-scale legal reform over a broad range of areas. The flexibility that could arise from the separation from EU norms presents a very significant opportunity for new practices and policy to develop.

Withdrawing from the European Union will result in the restitution of substantial legislative and administrative powers to national, regional and local governments. This presents an important potential opportunity for increasing decentralisation and devolution of power to the most appropriate level of government, those closest to citizens.

\section{Future threats}

The May government's proposed framework for legal separation from the EU and reform of UK law has significant flaws. It sacrificed certainty for speed by delegating broad and sweeping powers to government ministers - allowing them scope to change vast areas of law with little oversight or review from Parliament, which is undemocratic by nature and design.

The division of powers returned from the European Union between the UK national government in Whitehall and devolved governments is likely to be determined by the Westminster Parliament. Yet the de facto 'legislative supremacy of government' seems likely to increase further. In addition, concerns remain that more power will be centralised in Westminster, and the current powers of the devolved governments to act under EU law could be diminished (or even lost in some cases). 


\section{Future opportunities}

New bilateral relationships between the UK and other countries can be formed as the UK seeks to find new trading partners across the globe. Post-Brexit, there may be new demands for democratic input in the process of agreeing trade deals, where they have previously been within the prerogative power of the executive.

\section{Future threats}

The Brexit process represents a threat to rights based on EU law, for example, relating to workers, consumers, animals and the environment. These rights may be vulnerable to repeal where it becomes politically expedient to do so.

Rights codified by the EU's Charter of Fundamental Rights will not be converted into UK law, where they do not otherwise exist. The removal of robust remedies for the violation of rights systematically weakens current redress and remedy mechanisms against (ab)use of executive and legislative power.

\section{Is the European Union (Withdrawal) Act undemocratic?}

The European Union (Withdrawal) Act 2018 is designed to deliver both the legal separation of the UK from the EU, but also a degree of legal certainty within the UK following Brexit. The process will:

1. repeal the European Communities Act 1972;

2. convert directly effective EU law into UK law; and

3. delegate significant powers to the executive to remedy or prevent deficiencies arising from the conversion of EU Law (a 'Henry VIII' power').

The European Communities Act 1972 was the parliamentary act that previously (and until March 2019) gave effect and supremacy to EU law in the UK. It underlay a significant corpus of law in the UK by incorporating the acquis of EU membership, notably the EU Treaties and the EU Charter of Fundamental Rights, into British law. Repealing this Act without adequate transition mechanisms may result in a high degree of uncertainty about which law applies (or continues to apply), where and when. Many legal commentators have highlighted multiple concerns arising from the design of this process. The most significant issue relating to the democratic legitimacy of Brexit concerns the use of delegated powers by ministers. The EU (Withdrawal) Act delegates power to government ministers to create secondary legislation which will change, amend or remove retained EU-law on an unprecedented scope and scale. An estimated 800 to 1,000 statutory instruments have already been envisioned, but this is likely to be an underestimation of a possible 'legislative tsunami' that may result from this Act.

Constraints on the use of delegated powers to change or remove primary or secondary law are limited, while the power to determine where secondary legislation is needed is broad. Ministers will also decide the level of parliamentary scrutiny. Following criticisms in 
the Commons and Lords during the Withdrawal bill debates, a compromise was agreed to create a 'sifting committee' of MPs who will scrutinise statutory instruments. Yet this remains a weak device. And in some limited cases, instruments may even be made without any draft being laid before Parliament.

The likely delegation of legislative power away from Parliament raises pressing concerns for the accountability and transparency of the new arrangements, strengthening the legislative supremacy of the executive. Beyond the 'sifting committee' scrutiny, there is no proposed requirement on the government to provide explanation, justification or evaluation of the impact of their changes made to the law. This approach could compromise legal certainty and individual rights, and give government ministers leave to implement policy choices without Parliament. For all the intention of 'taking back control', such a design will be less democratic, create more uncertainty and ultimately weaken Parliament, as power is centralised in the hand of very few people in Whitehall.

\section{Will the jurisdiction of the European Court of Justice be undemocratic post-Brexit?}

To a significant extent the main 'Brexit issues' will be determined by a Withdrawal Agreement with the EU, and not by the UK's Parliament (or executive) acting alone. These issues include questions about the Northern Irish border with the Republic of Ireland; the rights of EU citizens resident in the UK and of UK citizens in the EU; Gibraltar; the settlement concerning the UK's remaining financial liabilities to the EU; and of course the future terms of trade between the UK and EU. However, these matters are just the headline issues so far. Many more issues will need settlement, including cooperation on matters of security, crime, family and civil judgments.

A key question has been whether the Court of Justice of the European Union (CJEU) has any jurisdiction in the UK following Brexit. The issue captured headlines following the 'red line' announced by Theresa May. The CJEU's function is to ensure the uniform application of EU law across all member states. It acts as a final arbiter in the case of disputes that fall within its jurisdiction, and provides an authoritative interpretation of EU law to be equally applied across all member states. Asking whether it is democratically legitimate to have regard to the jurisdiction of the CJEU is misplaced. In most liberal democracies, the judiciary are generally unelected in order to insulate them from the vagaries of day-today politics and to preserve judicial independence. Whether or not the UK will fall under the jurisdiction of the CJEU on certain EU-related issues post-Brexit remains part of the complex resolution of the future relationship between the UK and the EU, and will depend on whether it will be necessary for participation in the single market at least for goods.

\section{Could there be another 'Miller judgment'?}

The 2016 Miller judgment by the UK's Supreme Court was a powerful statement of the centrality of Parliament and the rule of law, above and beyond the powers of the executive. Under the judgment, the government alone does not have authority to make law which changes or removes domestic rights of individuals. To trigger Article 50, the government must be authorised to do so by an Act of Parliament. 
The key result of Miller was a brief (137-word) Act of Parliament that gave authority to the Prime Minister to notify the EU of the UK's intention to withdraw from the EU under Article 50. This Act did not give authority to the Prime Minister to agree to adopt the Withdrawal Agreement on behalf of the UK. (From the EU perspective, the Withdrawal Agreement would need to be adopted by a qualified majority vote, which requires that it is supported by at least $72 \%$ of the remaining 27 member states and representing at least $65 \%$ of the total EU population.) It can therefore be assumed that any withdrawal agreement must also be passed by the Westminster Parliament. Not doing so would likely result in Miller 2.0.

However, further questions around the Brexit process concern the immunisation of executive power from judicial challenge, and the removal or weakening of individual rights, by virtue of how withdrawal is implemented. Both of these concerns are at issue in the context of the European Union (Withdrawal) Act. It is highly likely there will be extensive litigation arising as a result of Brexit. The July 2017 Unison judgment concerning the constitutional right to access to justice can also be recognised as a shot across the bow from the Supreme Court for future Miller-type litigation. In a searing section of this judgment, the Supreme Court affirmed their role in ensuring that the executive carries out its functions in accordance with the law, and as regards its view on parliamentary democracy, the rule of law, and access to justice:

'Without such access [to the Courts], laws are liable to become a dead letter, the work done by Parliament may be rendered nugatory, and the democratic election of Members of Parliament may become a meaningless charade.' (R(Unison) v Lord Chancellor [2017] UKSC 51, at 58 (per Lord Reed).

We may guess how the courts will be likely to regard any Brexit process that does not respect these fundamental values.

\section{Would a second referendum deliver democratic legitimacy?}

The 2016 referendum delivered a result so surprising to all sides that no clear preparations had been made for a Leave vote, and subsequent revelations about the Leave campaign's breaches of spending limits and Russian interference in the campaign have both raised question marks about the legitimacy of the narrow Leave vote. However, campaigners for a second referendum for a long time faced barriers such as whether the Court of Justice of the EU (CJEU) would accept a second referendum after Article $\mathbf{5 0}$ had been triggered, and whether a second vote might not just easily produce another (perhaps larger) Leave majority.

However, opinion on the ground has changed and the lack of clarity about what Brexit deal will happen, including the continuing possibility of a no deal outcome, have strengthened demands for a referendum to confirm or reject the final arrangements. Many people are still hoping for the UK to remain a member state of the EU, and for them it may be a case of what was done by a referendum can only be undone by a referendum. From an external perspective, the question of whether it is possible to 'un-trigger' Article 50 is likely to be answered as a political rather than a legal question, and EU elites still believe it is likely in 
the affirmative. However, as the EU institutions and member states commit large time and investment in preparation for UK withdrawal, such political will may dissipate.

Critics (including this author) argue that such a referendum is at once too early and too late. It is too early for a deal to have been concluded (even in abstract) with the EU-27 which can then be put to referendum, and too late for the decision to be determined by the UK electorate as negotiations have begun. In practical terms, there is no frame of question that could be presented to the electorate that would satisfy all sides and be immune from accusations of bias or betrayal.

From a fundamental constitutional perspective, there should not be a second referendum on Brexit - because that would only serve to further undermine the system of parliamentary democracy. Unless we accept a radical reformulation of the constitutional foundations of the UK, a democratic Brexit process is one that reasserts Parliament's sovereignty over the 2016 referendum, but recognises that this sovereignty extends only to the UK borders - while Brexit reaches far, far beyond them.

\section{Conclusions}

Brexit has raised a great variety of legal issues and the development of the process has had some heartening and some worrying consequences for the UK public's understanding of the role of Parliament and legislation on the one hand, and of judges and the courts on the other. Amongst the most worrying have been the pillorying of judges in the media as 'enemies of the people' (an accusation that was not condemned by government ministers, and was perhaps even condoned by them), or attacks on the CJEU for a lack of democratic legitimacy. Both fundamentally misunderstand the whole notion of an independent judiciary, and the central values of the separation of judicial power from the executive and legislature and of the rule of law. Similarly virulent attacks on Remain MPs as 'saboteurs' for exercising judgement on implementation arrangements for Brexit reflect a poor understanding of what a legislature is for.

Dr Joelle Grogan is a Lecturer in Law at Middlesex University, and the creator of @StickyTrickyLaw. 